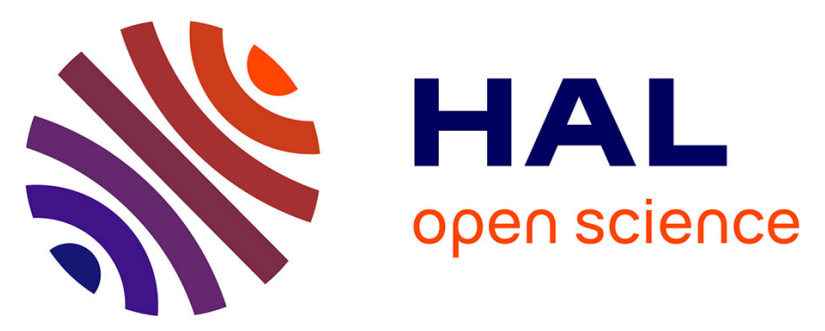

\title{
Dispersed phase volume fraction, weak acids and Tween 80 in a model emulsion: Effect on the germination and growth of Bacillus weihenstephanensis KBAB4 spores
}

L. Léonard-Akkari, S. Guégan, F. Courand, O. Couvert, J.F. Lepage, Corinne C. Rondeau-Mouro, N. Desriac, A.G. Mathot, I. Leguérinel, L. Coroller, et al.

\section{To cite this version:}

L. Léonard-Akkari, S. Guégan, F. Courand, O. Couvert, J.F. Lepage, et al.. Dispersed phase volume fraction, weak acids and Tween 80 in a model emulsion: Effect on the germination and growth of Bacillus weihenstephanensis KBAB4 spores. Food Research International, 2018, 109, pp.288-297. 10.1016/j.foodres.2018.04.016 . hal-01829591

\section{HAL Id: hal-01829591 \\ https://hal.science/hal-01829591}

Submitted on 4 Jul 2018

HAL is a multi-disciplinary open access archive for the deposit and dissemination of scientific research documents, whether they are published or not. The documents may come from teaching and research institutions in France or abroad, or from public or private research centers.
L'archive ouverte pluridisciplinaire HAL, est destinée au dépôt et à la diffusion de documents scientifiques de niveau recherche, publiés ou non, émanant des établissements d'enseignement et de recherche français ou étrangers, des laboratoires publics ou privés. 
LEONARD-AKKARI, L., GUeGAN, S., COURAND, F., COUVERT, O., LEPAGE, J.F., RONDEAU, C., DESRIAC, N., MATHOT, A.G., LEGUERINEL, I., COROLLER, L., DECOURCELLE, N. - 2018. Dispersed phase volume fraction, weak acids and Tween 80 in a model emulsion: Effect on the germination and growth of Bacillus weihenstephanensis KBAB4 spores. Food Research International, vol. 109, p. 288-297

Author-produced version of the final draft post-refeering. The original publication is available at $\mathrm{https}$ ://www.journals.elsevier.com/food-researchinternational - https://doi.org/10.1016/i.foodres.2018.04.016

Dispersed phase volume fraction, weak acids and Tween 80 in a model emulsion: Effect on the germination and growth of Bacillus weihenstephanensis KBAB4 spores

Lucie Léonard-Akkari ${ }^{1}$, Stéphanie Guégan ${ }^{1}$, Fabienne Courand ${ }^{2}$, Olivier Couvert ${ }^{1,4}$, Jean-François Lepage $^{2}$, Corinne Rondeau-Mouro ${ }^{3}$, Noémie Desriac ${ }^{1,5}$, Anne-Gabrielle Mathot ${ }^{1,5}$, Ivan Leguérinel ${ }^{1,5}$, Louis Coroller ${ }^{1,4}$, Nicolas Decourcelle ${ }^{1,4, *}$

${ }^{1}$ Université de Brest, EA 3882, Laboratoire Universitaire de Biodiversité et Ecologie Microbienne (LUBEM), UMT14.01 Spore Risk, 6 rue de l’Université, 29334 Quimper, France

${ }^{2}$ Adria Food Technology Institute - UMT14.01 Spore Risk, 20 avenue de la plage des Gueux, Quimper, France

${ }^{3}$ UR OPAALE, IRM-Food, IRSTEA, 17 avenue de Cucillé, 35044 Rennes, France

${ }^{4}$ Ecole Supérieure d'Ingénieurs en Agroalimentaire de Bretagne atlantique, 2 rue de l'Université, 29000 Quimper, France

${ }^{5}$ Institut Universitaire de Technologie de Quimper, 2 rue de l'Université, 29000 Quimper, France

* Corresponding author:

Dr. Nicolas Decourcelle

nicolas.decourcelle@univ-brest.fr

Tel: +33(0)2 98641947 
[Texte]

\section{Abstract}

In foodstuffs, physico-chemical interactions and/or physical constraints between spores, inhibitors and food components may exist. Thus, the objective of this study was to investigate such interactions using a model emulsion as a microbial medium in order to improve bacterial spore control with better knowledge of the interactions in the formulation.

Emulsions were prepared with hexadecane mixed with nutrient broth using sonication and were stabilized by Tween 80 and Span 80 . The hexadecane ratio was either $35 \%$ (v/v) or 50 $\%(\mathrm{v} / \mathrm{v})$ and each emulsion was studied in the presence of organic acid (acetic, lactic or hexanoic) at two pH levels (5.5 and 6). Self-diffusion coefficients of emulsion components and the organic acids were measured by Pulsed Field Gradient-Nuclear Magnetic Resonance (PFG-NMR). The inhibition effect on the spore germination and cell growth of Bacillus weihenstephanensis $\mathrm{KBAB} 4$ was characterized by the measure of the probability of growth using the most probable number methodology, and the measure of the time taken for the cells to germinate and grow using a single cell Bioscreen ${ }^{\circledR}$ method and using flow cytometry.

The inhibition of spore germination and growth in the model emulsion depended on the dispersed phase volume fraction and the $\mathrm{pH}$ value. The effect of the dispersed phase volume fraction was due to a combination of (i) the lipophilicity of the biocide, hexanoic acid, that may have had an impact on the distribution of organic acid between hexadecane and the aqueous phases and (ii) the antimicrobial activity of the emulsifier Tween 80 detected at the acidic $\mathrm{pH}$ value. The interface phenomena seemed to have a major influence. Future work will focus on the exploration of these phenomena at the interface.

\section{Keywords}

Bacillus, spoilage, antimicrobial effect, lipophilicity, emulsion, emulsifier

\section{Chemical compounds}

Acetic acid (PubChem CID: 176); Hexadecane (PubChem CID: 11006); Hexanoic acid (PubChem CID: 8892); Lactic acid (PubChem CID: 612); Tween 80 (PubChem CID: 5281955); Span 80 (PubChem CID: 9920342). 
[Texte]

\section{Introduction}

Growth of microorganisms in food emulsions can lead to major economic losses for the food industry through food-poisoning or spoilage due to the development of bacteria, yeasts and molds in food during shelf-life (Brocklehurst \& Wilson, 2000; Zalazar, Gliemmo, \& Campos, 2016). Two forms of emulsions are mostly encountered in food: oil-in-water (such as milk, dairy cream or mayonnaise) and water-in-oil (such as butter or low-fat spread) (Brocklehurst \& Wilson, 2000). Emulsions are metastable colloidal systems formed from two immiscible liquids (Wilson et al., 2002). Due to the large interfacial area between the two immiscible phases, emulsions are thermodynamically unstable systems and flocculation, coalescence and phase separation (e.g. creaming) are frequently observed during processing or storage (Mao, Wang, Liu, \& Gao, 2016). They can be stabilized kinetically because of the repulsion forces between neighboring droplets in the systems thanks to various components such as proteins, lipids and emulsifiers (Mao et al., 2016; Wilson et al., 2002). In such complex food emulsions, many factors may have effects on the behavior of microorganisms.

In emulsions, the aqueous phase is commonly recognized as a microbial growth location (Brocklehurst \& Wilson, 2000; Wilson et al., 2002), and the structural features of this phase are relevant to the length scale of the microorganisms that influence microbial growth (Wilson et al., 2002). Indeed, the food structure may influence both the growth rate and the conditions in which growth is initiated (Brocklehurst \& Wilson, 2000). The structure of complex matrices could also involve the formation of a local chemical specific micro-environment around microbial cells, for instance local pH (Robins \& Wilson, 1994). Thus, the surface of bacteria can interact physico-chemically with food matrix components such as proteins, lipids and emulsifiers. Electrostatic, Van Der Waals and Lewis acid-base interactions must also be considered between microbial surface properties and the environment (Ly et al., 2006). Bacterial cells are micrometer-scale particles bearing at their surface many macromolecules such as proteins, mannoproteins, peptidoglycan, teichoic acid and polysaccharides (Ly et al., 2008). Their surface composition can be modified by environmental chemical characteristics, as well as the adsorption of the oil phase on the bacterial outer surface (Naïtali, DuboisBrissonnet, Cuvelier, \& Bellon-Fontaine, 2009).

The structural complexity of food emulsions has a substantial impact on the activity of antimicrobial compounds (Terjung et al., 2014). Antimicrobial efficacy has been shown to depend on various product characteristics such as concentrations of fats, proteins, carbohydrates, and salt, as well as the pH (Castro, Rojas, Campos, \& Gerschenson, 2009; Jung, Bodyfelt, \& Daeschel, 1992; Terjung et al., 2014). However, difficulties in compiling 
[Texte]

the information and discrepancies in the literature remain since emulsion is a complex matrix exhibiting a wide diversity of compositions and physico-chemical characteristics.

The objective of this study was to investigate interactions between microorganisms, antimicrobial compounds and matrices. The model emulsion was composed of nutrient broth, allowing bacterial growth, as the aqueous phase, hexadecane as the dispersed phase and a Tween 80/Span 80 mixture as the emulsifier. These emulsifiers are non-ionic, frequently encountered in food systems (McClements \& Weiss, 2005) and listed as authorized additives under European regulations (EU 1129/2011 and EC 1333/2008 (https://eur-lex.europa.eu/)). According to the scientific literature, Tween 80 is particularly commonly used in food emulsions containing microorganisms and its concentration ranges from 0.1 to $10 \%(\mathrm{w} / \mathrm{w})$ (Buranasuksombat, Kwon, Turner, \& Bhandari, 2011; Celiktas et al., 2007; Hilbig, Ma, Davidson, Weiss, \& Zhong, 2016; Krogsgard-Nielsen et al., 2017; Landry et al., 2016; Murray, 2016; Neves et al., 2016; Ribes, Fuentes, Talens, \& Barat, 2017). Both emulsifiers were chosen to stabilize the emulsion because of this non-ionic characteristic to limit artefacts. The use of hexadecane prevented any trace of polyunsaturated fatty acid which could affect microorganism behavior (Mvou Lekogo, Coroller, Mathot, Mafart, \& Leguérinel, 2010). The emulsion characteristics ( $\mathrm{pH}$, weak acid and dispersed phase volume ratio) were modified and the impacts were assessed on several scales, namely Bacillus weihenstephanensis germination and outgrowth, and the interface phenomenon with the emulsifier. Bacillus weihenstephanensis was used in this study because of its capacity i) to contaminate chilled and minimally processed food, ii) to constitute a potential danger for customers' health, and iii) to limit products' shelf life leading to economic losses (Antolinos et al., 2012; Desriac et al., 2013).

\section{Materials and methods}

\subsection{Model system preparation}

The model emulsion was composed of nutrient broth as the aqueous phase, hexadecane as the dispersed phase and a Tween 80/Span 80 mixture as the emulsifier. This emulsion was inoculated with Bacillus weihenstephanensis spores or vegetative cells.

\subsubsection{Inoculum preparation}

Bacillus weihenstephanensis strain KBAB4 (INRA, Avignon, France) was used in this study. The strain (in the form of vegetative cells) was stored at $-80{ }^{\circ} \mathrm{C}$ in Brain Heart Infusion (BHI) (Biokar, Diagnostics, Beauvais, France) mixed with $50 \%$ glycerol (v/v). A 100-mL volume of BHI was inoculated with $1 \mathrm{~mL}$ of the stock suspension and incubated for $8 \mathrm{~h}$ at $30{ }^{\circ} \mathrm{C}$, the 
[Texte]

optimal growth temperature; then, a 1-mL volume was transferred into $100 \mathrm{~mL}$ of BHI for $16 \mathrm{~h}$ at $30{ }^{\circ} \mathrm{C}$. Finally, $0.1 \mathrm{~mL}$ of the Bacillus weihenstephanensis suspension was added to $100 \mathrm{~mL}$ of BHI and was incubated for $6 \mathrm{~h}$. Spores were produced through a two-step sporulation process as described in Baril et al. (2011). The final concentration of the bacterial spore suspension was $10^{7}$ spores $\cdot \mathrm{mL}^{-1}$. The number of spores was estimated as the number of cells surviving a 5 -min, $70^{\circ} \mathrm{C}$ heat treatment.

\subsubsection{Emulsion preparation}

Hexadecane (H6703, Sigma Aldrich, St-Louis, MO, USA) was mixed with nutrient broth (Biokar, Diagnostics, Beauvais, France) using sonication and stabilized by Tween 80 (P4780, Sigma Aldrich, St-Louis, MO, USA) and Span 80 (S6760, Sigma Aldrich, St-Louis, MO, USA). Emulsions with either $35 \%(\mathrm{v} / \mathrm{v})$ (dispersed phase volume ratio $(\phi)=0.35)$ or $50 \%$ $(\mathrm{v} / \mathrm{v})(\phi=0.50)$ hexadecane content were studied as a function of $\mathrm{pH}$ (5.5 and 6.0), adjusted with $\mathrm{HCl}$, with or without weak acid. Three weak acids were studied as antimicrobial compounds: acetic acid $(p K a=4.75 ; \log P=0.17)$ (A6283, Sigma Aldrich, St-Louis, MO, USA), hexanoic acid $(p K a=4.88 ; \log P=1.92)(153745$, Sigma Aldrich, St-Louis, MO, USA) and lactic acid ( $p K a=3.90 ; \log P=-0.72)$ (69775, Sigma Aldrich, St-Louis, MO, USA). The $\log P$ values were assessed by Hansch and Leo (1995). Acetic acid and lactic acid were studied as food additives. Hexanoic acid was studied because of its higher hydrophobicity $(\log P=1.92)$ compared to acetic acid and lactic acid $(\log P=0.17$ and $\log P=-0.72$, respectively).

The aqueous phases were composed of $0.005 \%$ iron citrate, $0.1 \%$ esculin, $2 \%$ nutrient broth, $3 \%$ Tween 80 for emulsions with $\phi=0.50$ and $2.3 \%$ Tween 80 for emulsions with $\phi=0.35$ ( $\% \mathrm{w} / \mathrm{w}$ of the aqueous phase). A weak acid was mixed with the aqueous phase during the preparation process to obtain final concentrations of $14 \mathrm{mM}$ of acetic acid, 1.8 and $4 \mathrm{mM}$ of hexanoic acid, and 82 and $255 \mathrm{mM}$ of lactic acid. Hexadecane and the aqueous phases were sterilized by filtration $\left(0.22 \mu \mathrm{m}\right.$, Stericup ${ }^{\circledR}$ Millipore $)$ prior to spore inoculation. Heat-treated spore suspension $\left(5 \mathrm{~min}\right.$; $\left.70{ }^{\circ} \mathrm{C}\right)$ was added to the aqueous phase at three different concentrations: 100, 20 and 3.5 spores per $100 \mu \mathrm{L}$ of aqueous phase. The mixtures were sonicated for $1 \mathrm{~min}$ at $60 \%$ amplitude using a Branson $450 \mathrm{~W}-20 \mathrm{kHz}$ digital sonifier equipped with a temperature probe. Thus, for each sample the temperature variation was controlled and rose $40{ }^{\circ} \mathrm{C}$ in $1 \mathrm{~min}$ of mixing.

\subsection{Physical characterization of emulsions and microbial cells}

\subsubsection{Droplet size and stability}


[Texte]

The emulsion particle size distributions were measured by laser granulometry with a Malvern MS3000, in $0.1 \%$ SDS dispersant at $2000 \mathrm{rpm}$. The mean volume diameters $\mathrm{D}_{[4,3]}$ and the particle size dispersions were monitored for 10 days with storage at $30{ }^{\circ} \mathrm{C}$ which was the temperature used for the microbial assay. The emulsion stability (flocculation, creaming, clarification) was monitored by multiple light scattering with a TurbiScan (Formulaction, France). The destabilization phenomena were monitored for 10 days at $30{ }^{\circ} \mathrm{C}$.

\subsubsection{Zeta potential measurements}

According to Bundeleva et al. (2011), zeta-potential ( $\xi$-potential) can be used to perform the change in the cell surface potential $(\mathrm{mV})$ of microorganisms as a function of $\mathrm{pH}$. $\xi$-potential is an important parameter to analyze the stability of particles (MubarakAli et al., 2018).

The $\xi$-potential of vegetative cells and spores was measured using a Zetasizer Nano-ZS (Malvern Instruments, United Kingdom). The analysis was performed at $25^{\circ} \mathrm{C}$ between $\mathrm{pH} 4$ and 9; a range covering those used for the microbial assay. Vegetative cells were recovered from a culture in the exponential phase with an optical density of 0.5 at $600 \mathrm{~nm}$ and washed twice in tryptone salt medium. The vegetative cell suspension and spore stock suspension were diluted 10 - and 1000 -fold respectively in $5 \mathrm{mmol} \cdot \mathrm{L}^{-1}$ of imidazole/acetate buffer adjusted to the appropriate $\mathrm{pH}$ using $\mathrm{NaOH}$ or $\mathrm{HCl}$ solutions $\left(1 \mathrm{~mol} \cdot \mathrm{L}^{-1}\right)$ prior to measurements. Samples were introduced into capillary cells and measured in automatic mode. The $\xi$-potential measurements are reported as the average and standard deviation of the measurements for three freshly prepared samples.

\subsubsection{Surface hydrophobicity}

The hydrophobicity of vegetative cells and spores was evaluated by Microbial Adhesion to Hexadecane (MATH) (Bellon-Fontaine, Rault, \& van Oss, 1996). Vegetative cells in the exponential phase were harvested by centrifugation at $5000 \mathrm{~g}$ for $10 \mathrm{~min}$ at $4{ }^{\circ} \mathrm{C}$, washed twice in tryptone salt medium and resuspended to $\mathrm{A}_{600 \mathrm{~nm}}=0.5\left(\mathrm{~A}_{0}\right)$ in physiological water. $0.5 \mathrm{~mL}$ of hexadecane was added to $3 \mathrm{~mL}$ of cell or spore suspension with optical density $\mathrm{A}_{0}$. The two-phase system was mixed by $10 \mathrm{~s}$ shaking by hand, then by vortexing $1 \mathrm{~min}$, and finally by $10 \mathrm{~s}$ shaking by hand. The system was allowed to separate for $15 \mathrm{~min}$. The absorbance of the aqueous phase at $600 \mathrm{~nm}\left(\mathrm{~A}_{1}\right)$ was measured. The percentage of microbial adhesion (Ad\%) to solvent was calculated as follows (1):

$$
A d \%=\left(1-\frac{A_{1}}{A_{0}}\right) \times 100
$$

\subsubsection{Microscopy}


[Texte]

186

187

188

189

190

191

192

193

194

195

196

197

198

199

200

201

202

203

204

205

206

207

208

209

210

211

212

213

214

215

216

Microstructures of the model emulsion containing spores were observed with a Confocal Laser Scanning Microscope (CLSM) Zeiss LSM780 (Carl Zeiss, Oberkochen, Germany). The hexadecane was stained with Nile Red (72485, Sigma Aldrich, St-Louis, MO, USA) (emission/excitation wave length: 488-515/>590 nm) at a final concentration of $16 \mathrm{mg} \cdot \mathrm{mL}^{-1}$. Spores were labeled with Thioflavin T (T3516, Sigma Aldrich, St-Louis, MO, USA) (emission/excitation wave length: $405 / 485 \mathrm{~nm}$ ) at a final concentration of $100 \mu \mathrm{mol} \cdot \mathrm{L}^{-1}$ of spore suspension. Two light sources were used: a diode laser at $405 \mathrm{~nm}$ and an Argon laser at $514 \mathrm{~nm}$.

\subsubsection{Pulsed Field Gradient-Nuclear Magnetic Resonance (PFG-NMR)}

NMR measurements were performed at $30{ }^{\circ} \mathrm{C}$ with a $500 \mathrm{MHz}$ Bruker spectrometer, equipped with a field gradient probe ( 0 to $12 \mathrm{~T} / \mathrm{m}$ ) and using the LED-BP-PFGSTE sequence in which $\Delta$ is the diffusion delay (5.64 to $100 \mathrm{~ms})$ and $\delta$ the gradient pulse duration $(1 \mathrm{~ms})$. Within a measurement, sequence parameters $\delta, \Delta$ and $\tau$ (time between the end of each gradient and the next radiofrequency pulse) $(1 \mathrm{~ms})$ remained constant and successive and increasing values of the gradient amplitude (g) were applied.

The data was processed using the Dynamics Center (DOSY reconstruction) and the T1/T2 relaxation module (1D processing) developed by Bruker under Topspin 3.2. For 1D processing, the self-diffusion coefficient (D) was determined on the basis of the following equation (2):

$\frac{I_{g}}{I_{0}}=\exp \left[-\gamma^{2} \times g^{2} \times \delta^{2} \times\left(\Delta-\frac{\delta}{3}-\frac{\tau}{4}\right) \times D\right]$

(assuming in this case monoexponential decay), where $I_{g}$ is the attenuated signal intensity by application of gradient pulses, $I_{0}$ the optimum signal intensity without field gradient, and $\gamma$ the gyromagnetic ratio). The self-diffusion coefficient (D0) were $4.50 \times 10^{-11} \pm 7.50 \times 10^{-13} \mathrm{~m}^{2} \cdot \mathrm{s}^{-}$ ${ }^{1}, 4.15 \times 10^{-10} \pm 1.0 \times 10^{-12} \mathrm{~m}^{2} \cdot \mathrm{s}^{-1}, 1.24 \times 10^{-09} \pm 3.0 \times 10^{-12} \mathrm{~m}^{2} \cdot \mathrm{s}^{-1}$ and $5.10 \times 10^{-11} \pm 1.63 \times 10^{-}$ ${ }^{12} \mathrm{~m}^{2} \cdot \mathrm{s}^{-1}$, for pure lactic acid, hexanoic acid, acetic acid and Tween 80 , respectively. Then, each weak acid and Tween 80 were diluted in water $(\phi=0)$ or prepared in two different emulsions with $\phi=0.35$ and with $\phi=0.50$. For each acid, the self-diffusion coefficient D in water or emulsions was compared to D0 (pure weak acid or Tween 80) by calculating the ratio D/D0.

\subsection{Characterization of bacterial behavior}


[Texte]

2.3.1 Assessment of the number of spores able to germinate and to grow in emulsion

The inoculated emulsions were distributed in sterile 96-well microplates. Spores of Bacillus weihenstephanensis $\mathrm{KBAB} 4$ able to germinate and to outgrow were detected by the loss of fluorescence of wells due to the esculin metabolism. These spores were then enumerated by the most probable number method (MPN). An estimation of the percentage of spores able to germinate and to give active cells in the emulsion was calculated as follows (3):

OutG\% $=\left(\frac{M P N}{N_{0}}\right) \times 100$

with $N_{0}$ (Colony Forming Unit, CFU), the initial population of spores determined after a 5min, $70{ }^{\circ} \mathrm{C}$ heat treatment and dilution in tryptone salt broth (Biokar, Diagnostics, Beauvais, France) by plating in nutrient agar (Biokar, Diagnostics, Beauvais, France).

\subsubsection{Monitoring Bacillus spore germination by flow cytometry}

Spore germination and outgrowth in nutrient broth in the presence of Tween 80 were monitored by flow cytometry (FCM) analysis using the fluorescent dye Syto®9 (Invitrogen, Carlsbad, California, United States) to investigate the effect of the emulsifier at different $\mathrm{pH}$ values on spores. Syto®9 fluoresces only when bound to either double-stranded DNA or RNA with an emission maximum of $520 \mathrm{~nm}$ (green). Dormant refractive spores show only peripheral staining with Syto®9, however, intact germinating spores stain brightly (van Melis, Groot, Tempelaars, Moezelaar, \& Abee, 2011). For $1 \mathrm{~mL}$ of culture sample, $0.5 \mu \mathrm{L}$ of Syto®9 was added (van Melis et al., 2011). Flow cytometric analyses were carried out using a CyFlow ${ }^{\circledR S p a c e}$ (Partec, France). Forward (FSC) and side (SSC) scatter signals were collected from $488 \mathrm{~nm}$ excitation. Analysis was carried out in true volumetric absolute counting mode (analysis in $200 \mu \mathrm{L}$ ). Samples were diluted with tryptone salt broth prior to analysis in order to respect a sampling rate ranging from 500 to 5000 particles $\cdot \mathrm{s}^{-1}$. Analysis and gating of data were performed using FloMax® software (Partec, France).

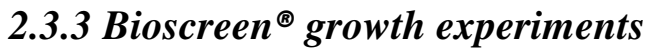

The growth kinetics of Bacillus weihenstephanensis KBAB4 were evaluated in nutrient broth at $30{ }^{\circ} \mathrm{C}$ with different concentrations of Tween $80(0,1,5$ and $10 \%(\mathrm{w} / \mathrm{w}))$ to investigate the effect of the emulsifier at different $\mathrm{pH}$ values on vegetative cells. Turbidity growth curves were generated with an automatic Bioscreen $\mathrm{C}$ reader (Oy Growth Curves Ab Ltd., Helsinki, Finland). From a pre-culture in the end exponential phase, the first line of a plate was inoculated with a $10^{5} \mathrm{CFU} \cdot \mathrm{mL}^{-1}$ suspension and, to complete the plate, seven serial two-fold 
[Texte]

250

251

252

253

254

255

256

257

258

259

260

261

262

263

264

265

266

267

268

269

270

271

272

273

274

275

276

277

dilutions were performed in the tested medium. Then the plate was placed in the Bioscreen $\mathrm{C}$ reader at $30{ }^{\circ} \mathrm{C}$. The increase in turbidity was monitored at $600 \mathrm{~nm}$. Measurements were taken every $10 \mathrm{~min}$, and the plate was shaken at low intensity for $20 \mathrm{~s}$ prior to absorbance measurements. The maximum specific growth rate $\left(\mu_{\max }\right)$ values corresponding to each Tween 80 concentration were determined by linear regression as previously described (Membré et al., 2005). Paired Student's $t$-tests were performed to compare the maximum specific growth with and without Tween 80 . P-values strictly lower than 0.05 were considered significant.

\subsubsection{Individual lag times}

The distribution of individual lag times was investigated according to a method adapted from Guillier et al. (2005). From end exponential phase cells, serial dilutions were performed in the tested medium in order to obtain a final bacterial suspension at $1.4 \mathrm{CFU} \cdot \mathrm{mL}^{-1}$. Assuming thereafter that the distribution of the cells in the microplate followed a Poisson distribution, the maximum concentration of $0.42 \mathrm{CFU} \cdot \mathrm{well}^{-1}$ will correspond to a maximum of $35 \%$ of wells showing growth and $20 \%$ of them, i.e. $7 \%$, will only have one cell.

Then the plate was placed in the Bioscreen $\mathrm{C}$ reader at an incubation temperature of $30{ }^{\circ} \mathrm{C}$. The increase in turbidity was monitored at $600 \mathrm{~nm}$. Measurements were taken every $10 \mathrm{~min}$, and the plate was shaken at low intensity for $20 \mathrm{~s}$ prior to absorbance measurements.

On the assumption that the maximum specific growth rate was constant from one well to another, the detection time $\left(\mathrm{T}_{\mathrm{d}}\right)$ is related to the lag time (lag) by the following formula (Baranyi \& Pin, 1999) (4):

$T_{d}=\operatorname{lag}+\frac{\ln \left(N_{d}\right)-\ln \left(N_{0}\right)}{\mu_{\max }}$

with $N_{d}$, the bacterial number at $T_{d}$; $N_{0}$, the number of cells initiating growth in the considered well, and $\mu_{\max }$, the maximum specific growth rate.

The Kolmogorov-Smirnov statistical test was applied to compare the distributions of latency times with and without Tween 80 at one $\mathrm{pH}$ value (XLSTAT software, 2017 version).

\section{Results}

\subsection{Physical characteristics of emulsion constituents}

\subsubsection{Droplet size}

The dispersion was studied to characterize the spatial organization and locate the different components. Measurements by laser granulometry showed that emulsions with $\phi=0.35$ and $\phi=0.50$ were monodispersed. Indeed, an emulsion is considered concentrated when it reaches 
[Texte]

283

284

285

286

287

288

289

290

291

292

293

294

295

296

297

298

299

300

301

302

303

304

305

306

307

308

309

310

311

312

313

314

315

a concentration $64 \%$ of monodisperse droplets, which represents the random-close-packing volume fraction (Leal-Calderon, Schmitt, \& Bibette, 2007). The droplets were agitated by a Brownian motion. They presented a monomodal distribution of hexadecane droplets with, respectively, a $\mathrm{D}_{[4,3]}$ of $0.484 \pm 0.005 \mu \mathrm{m}$ and $0.437 \pm 0.006 \mu \mathrm{m}$. During a 10-day period at 30 ${ }^{\circ} \mathrm{C}$, neither the creaming nor the stability of the emulsions was modified with or without organic acid and whatever the $\mathrm{pH}$. As observed in the emulsions using confocal microscopy (Figure 1), the droplets of the dispersed phase appeared to be smaller than the spores $(\sim 1 \mu \mathrm{m})$ (Carrera, Zandomeni, Fitzgibbon, \& Sagripanti, 2007). In our systems, microbial growth seemed to occur in the aqueous phase as is commonly recognized (Brocklehurst \& Wilson, 2000; Wilson et al., 2002).

\subsubsection{Spore characteristics}

The surface of the spores and vegetative cells were characterized by MATH (BellonFontaine et al., 1996). We found that the spores had a hydrophobic surface contrary to vegetative cells. The $\xi$-potential values of spores and vegetative cells, i.e. net charges on the surface, were also determined in phosphate buffer ranging from $\mathrm{pH} 4$ to 9 . The electrophoretic motilities of the spores and vegetative cells indicated an electronegative character with $\xi$ potential ranging, respectively, from -9.8 to $-41.0 \mathrm{mV}$ and from -11.2 to $-18.7 \mathrm{mV}$.

\subsubsection{Diffusion of emulsion constituents by NMR}

In order to highlight the effect of emulsion structure on the diffusion coefficients of weak acids, the $\mathrm{D} / \mathrm{D}_{0}$ ratio was reported as a function of $\mathrm{pH}$ for each hexadecane/water ratio (Figure 2). The D/D0 ratio variations were significant as showed by the calculated standard error for each ratio. Figure 2 shows that for each weak acid, whatever the $\mathrm{pH}, \mathrm{D} / \mathrm{D}_{0}$ tended to decrease when the hexadecane/water ratio increased. This indicates that a fraction of each weak acid may be trapped in the hexadecane, and/or the emulsion structure impacts on its diffusion coefficient. Discrepancies of $\mathrm{D} / \mathrm{D}_{0}$ values among acids were likely due to two effects: $\mathrm{D} / \mathrm{D}_{0}>1$ may be due to a lower viscosity in water or in emulsion in comparison to bulk acid, and $\mathrm{D} / \mathrm{D}_{0}<1$ may be due to a structure effect in emulsion either by molecule trapping or interactions between weak acids and droplets. These results were obtained by assuming that the total amount of weak acid was diffused in the emulsion in a unique way (mono-exponential decrease of the NMR signal). In contrast to lactic acid and acetic acid, $\mathrm{D} / \mathrm{D}_{0}$ for hexanoic acid tends to decrease with $\mathrm{pH}$ (Figure 2.a). This discrepancy could account for both the higher $p K a$ and the higher $\log P$ for hexanoic acid, favoring its affinity for the dispersed hexadecane phase. 
[Texte]

316 For Tween 80, the self-diffusion coefficient was around $10^{-11} \mathrm{~m}^{2} \cdot \mathrm{s}^{-1}$ in water and around

$31710^{-10} \mathrm{~m}^{2} \cdot \mathrm{s}^{-1}$ in emulsions, whatever the $\mathrm{pH}$ value and hexadecane volume fraction. These two 318 different values might be due to the spatial arrangement of Tween 80 in the form of micelles 319 in water and at the emulsion interfaces (Henry, Fryer, Frith, \& Norton, 2009).

320

3.2 Comparison of the percentage of outgrown B. weihenstephanensis spores in aqueous phases and model emulsions

An estimation of the percentage of outgrown B. weihenstephanensis KBAB4 spores (i) in the nutrient broth, (ii) in the aqueous phase (nutrient broth with $3 \%(\mathrm{w} / \mathrm{w})$ Tween $80(\phi=0)$ ), (iii) in $\phi=0.35$ emulsions and (iv) in $\phi=0.50$ emulsions was calculated from an enumeration by a most probable number (MPN) assay.

First of all, the percentage of germination and outgrowth in the nutrient broth with $\mathrm{HCl}$ at $\mathrm{pH}$ 5.5 was 1.5-fold lower compared to $\mathrm{pH} 6$ (Table 1). The percentages of germination and outgrowth obtained with the weak acids was 0 to 1.2-fold lower than with $\mathrm{HCl}$ at $\mathrm{pH} 6.0$ and 1.3 to 2.8 -fold lower at $\mathrm{pH} 5.5$.

Secondly, the percentages of germination and outgrowth in the aqueous phase (nutrient broth with $3 \%(w / w)$ Tween $80(\phi=0))$ used for the emulsion with $\mathrm{HCl}$ at $\mathrm{pH} 5.5$ were lower than those at $\mathrm{pH} 6$, also reflecting the influence of $\mathrm{pH}$ on B. weihenstephanensis KBAB4 (Table 1). Yet, we noticed that the aqueous phase $(\phi=0)$ in the presence of the weak acids and $\mathrm{HCl}$ at $\mathrm{pH} 5.5$ revealed that less than $0.03 \%$ of spores outgrew compared to 22 to $61 \%$ in the nutrient broth. This highlighted an antimicrobial synergistic effect between Tween 80 and weak acid depending on the $\mathrm{pH}$ value.

Moreover, the percentages of outgrowth observed in all $\phi=0.35$ emulsions as well as those observed in the $\phi=0.50$ emulsions with lactic acid and acetic acid at pH 5.5 and pH 6 did not differ from the aqueous phase (Table 1). Surprisingly, data in Table 1 show that the $\phi=0.50$ emulsions with $\mathrm{HCl}$ at $\mathrm{pH} 5.5$ revealed a higher percentage of outgrowth compared to the aqueous phase or the $\phi=0.35$ emulsions with $\mathrm{HCl}$ at the same $\mathrm{pH}$ value. In the same way, these data also show that the $\phi=0.50$ emulsions with hexanoic acid at $\mathrm{pH} 6$ revealed a higher percentage of outgrowth compared to the aqueous phase or the $\phi=0.35$ emulsions with hexanoic acid at the same $\mathrm{pH}$ value.

These results confirm the influence of $\mathrm{pH}$ and of the weak acids as hurdles preventing the germination and outgrowth of B. weihenstephanensis KBAB4 in the studied systems. Yet, Tween 80, used as the emulsifier in the emulsions, also acted as an additional hurdle. Furthermore, the ability of spores to recover and grow was modulated by the interactions 
[Texte]

350

351

352

353

354

355

356

357

358

359

360

361

362

363

364

365

366

367

368

369

370

371

372

373

374

375

376

377

378

379

380

381

382

383

among Tween 80, hexanoic acid and their environment. This illustrated the complexity of controlling the bacterial behavior through physico-chemical factors in complex matrices.

\subsection{Effect of Tween 80 on the growth of vegetative cells ( $\mu_{\max }$, lag times)}

In order to characterize the antimicrobial effect of Tween 80 on the growth of KBAB4 cells, Bioscreen ${ }^{\circledR}$ growth experiments were carried out to determine growth parameters in the presence or absence of Tween 80 at pH 5.5 and pH 6.0 (Figure 3). At pH 6.0 with a Tween 80 concentration of $5 \%(\mathrm{w} / \mathrm{w})$ and more, $\mu_{\max }$ was significantly lower than the control without Tween 80 . At pH 5.5 with a Tween 80 concentration of $2 \%$ and more, $\mu_{\max }$ was significantly lower than without Tween 80 (Student's $t$-test, $\mathrm{p}<0.05$ ). Tween 80 seemed to have an antimicrobial effect on the growth of vegetative cells depending on the $\mathrm{pH}$ value. Minimum inhibitory concentrations were determined by a linear regression: at $\mathrm{pH}$ 6.0, MIC was $64.8 \%(\mathrm{w} / \mathrm{w})$ and at $\mathrm{pH} 5.5$, MIC was $19.9 \%(\mathrm{w} / \mathrm{w})$.

The distribution of individual lag times of vegetative cells with and without Tween 80 at $\mathrm{pH}$ 6.0 and 5.5 were assessed (Figure 4). The presence of Tween 80 in the growth medium increased the individual lag times. At $\mathrm{pH}$, the frequency distribution was maximal for the 10-11 h lag time interval without Tween 80, and for the 10-12 h interval with Tween 80 . At $\mathrm{pH} 5.5$, the frequency distribution was maximal for the 12-13 h lag time interval without Tween 80 , and for the 16-18 h interval with Tween 80 . The effect of Tween 80 on the growth delay was more marked at acidic pH (higher D statistic at pH 5.5 (Kolmogorov-Smirnov statistical test)). The frequency distributions without Tween 80 and with Tween 80 were significantly different at both $\mathrm{pH}$ values (Kolmogorov-Smirnov statistical test). As shown by these results, at pH 5.5 and with Tween 80, the variability of lag times was higher than for any other combination tested, which indicates that, at single cell level, the adaptation period, and therefore the lag times, had a much greater variability than in the other conditions tested. This indicates that the combination has an important inhibitory effect on cells.

\subsection{Effect of Tween 80 on spore germination (kinetics determined by flow cytometry)}

To determine whether Tween 80 induced a delay in germination, spores were exposed to different concentrations of Tween 80 in nutrient broth at $\mathrm{pH} 5.5$ and their germination was monitored by flow cytometry (Figure 5). According to van Melis et al. (2011), dormant refractive spores are slightly stained (Figure 5, quadrant I). Upon germination, spore permeability to Syto®9 and the accessibility of DNA increased, leading to an increase in the 
[Texte]

384

385

386

387

388

389

390

391

392

393

394

395

396

397

398

399

400

401

402

403

404

405

406

407

408

409

410

411

412

413

414

415

416

fluorescence level (Figure 5, quadrant II). The size increase of the outgrowing spores could then be monitored by an increase in the forward-scatter signal (Figure 5, quadrant III).

After $4 \mathrm{~h}$, for all the conditions, the spores were still dormant. Within the following four hours, the spore populations became permeable to Syto®9 (quadrant II, germinated spores). Under unstressed conditions (without Tween 80), the majority of the cell population was able to outgrow (located in quadrant III), while for stress conditions, a substantial part of the spore population remained dormant (quadrant I) until $10 \mathrm{~h}$ of incubation. Without Tween 80, $4.59 \%$ of spores were still refractive spores (quadrant I) after $10 \mathrm{~h}$ of incubation, while with $5 \%$ and $10 \%$ of Tween 80 in nutrient broth, the percentage of dormant spores was respectively 12.04 $\%$ and $54.59 \%$. It can also been seen from Figure 5C that after $8 \mathrm{~h}$ and $10 \mathrm{~h}$ germinated spores and growth (quadrant II and quadrant III, respectively) decreased more sharply than for other conditions. Thus, increasing the concentration of Tween 80 drastically decreased germination and growth.

\section{Discussion}

First of all, $\mathrm{H}^{+}$ion concentrations had an effect on spore germination and outgrowth as expected. $\mathrm{H}^{+}$ions will move into the cytoplasm decreasing internal $\mathrm{pH}$. Drastic variations in cytoplasmic $\mathrm{pH}$ can harm bacteria by disrupting the plasma membrane or inhibiting enzyme activities and membrane transport proteins. Changes in the external $\mathrm{pH}$ might also alter the ionization of nutrient molecules and thus reduce their availability to the organism. In our model emulsion, the effect of $\mathrm{pH}$ was detected at $\mathrm{pH} 5.5$ regardless of the dispersed phase volume fraction. Nevertheless, at $\mathrm{pH} 5.5$ less than $0.03 \%$ germination and outgrowth may occur. The minimum growth $\mathrm{pH}$ value is 4.35 and the estimated optimal recovery $\mathrm{pH}$ is 7.80 for B. weihenstephanensis KBAB4 (Trunet et al., 2015). This result suggested a synergistic effect between $\mathrm{pH}$ value and matrix composition.

The role of undissociated weak acid molecules was also important. Weak acids are the most commonly used chemical preservatives in the food industry to control both $\mathrm{pH}$ and microbial growth (van Melis et al., 2011). It is generally accepted that that bacterial growth inhibition by weak acids is based on the rapid diffusion of undissociated molecules through the plasma membrane, followed by immediate dissociation and acidification of the cytoplasm. Concerning their effects on bacterial spores, van Melis et al. (2012) formulated two possibilities. Inhibition could be due, on one hand, to the accumulation of acids in the spore 
[Texte]

inner membrane or, on the other hand, to the accumulation of foreign compounds in the inner membrane. As we have shown, such effects may occur in emulsions and may be affected by the dispersed phase volume fraction and the presence of Tween 80. These relevant effects should be highlighted and characterized, as they may have important safety implications in foods based on emulsions.

There was no influence of the dispersed phase volume fraction in the presence of acetic acid and lactic acid, whereas hexanoic acid was less effective in $\phi=0.50$ emulsions. However, results contrary to ours are described in the literature. Prachaiyo and McLandsborough (2003) showed an increase in the generation time of bacteria as the hexadecane concentration increased. This is likely to be due to space limitation, nutrient limitation and/or the concentration of metabolic products. In the same way, Zalazar et al. (2016) described how an increase in the oil level promoted a decrease in the specific growth rate. On the other hand, Dong et al. (2016) reported a comparable inactivation of Bacillus amyloliquefaciens spores by thermal and high hydrostatic pressure treatments in an oil/water emulsion with $20 \%$ and $10 \%$ soybean oil. As the dispersed phase droplets in our study were smaller than the $B$. weihenstephanensis KBAB4 spores, the cells seemed to evolve in the aqueous phase following a Brownian motion and the increase in hexadecane concentration did not have an effect on the germination and growth percentage.

In addition, our results showed a decline in efficiency of hexanoic acid with the increase in hexadecane concentration. This could be related to the lipophilic character of this weak acid. Indeed, according to the NMR results, the impact of hexadecane/water ratio impacted the hexanoic acid diffusion coefficient more, which decreased with the $\mathrm{pH}$. This could mean that a fraction of hexanoic acid may be trapped in the dispersed phase limiting its access to cells that were in the aqueous phase. Similarly, Brocklehurst and Wilson (2000) wrote that the weak acid components interact with the lipid phase, and the effect was a decrease in the preservation of the products. For example, acetic acid had a low partition coefficient: just a small proportion of this acid was dissolved in the lipid phase and therefore predominantly available in the water phase as a preservative. This was not the case for sorbic acid or benzoic acid which had respectively a $\log P$-value of 1.33 and 1.87 . Furthermore, in most emulsified food, emulsifiers are above their critical micelle concentration at which aggregates known as micelles are formed. The non-polar inner regions of micelles present an environment closely similar to that created by an organic solvent, where solutes such as weak acid will tend to partition. For this reason, the preservative effectiveness of a weak acid will be associated with its distribution in the different phases of the food emulsion, considering the interior of the 
[Texte]

451

452

453

454

455

456

457

458

459

460

461

462

463

464

465

466

467

468

469

470

471

472

473

474

475

476

477

478

479

480

481

482

483

484

micelles as a third phase (Castro et al., 2009). In our system, the lipophilicity of the biocide, hexanoic acid, seemed to have had an impact on the distribution of the weak acid between the dispersed phase and the aqueous phase and thus, on the antimicrobial activity.

Moreover, the structure and composition of the model emulsion seemed to affect antimicrobial activity. The loss of microbial inhibitory activity when the dispersed phase volume fraction increased could be due to phenomena at the interfaces. Factors such as hydrophobicity, surface charge, and cell density influence the attachment of microorganisms to surfaces and the behavior at interfaces (Seale, Flint, McQuillan, \& Bremer, 2008). The main result that emerged from the work of Naïtali et al. (2009) was that the cell surface hydrophobicity of Listeria monocytogenes increased after growth in emulsion. This may have been due to modifications to the cell surface composition, as well as to the adsorption of the oil phase on the outer surface of the bacteria (Naïtali et al., 2009). The hydrophobicity of various species of the B. cereus group spores varies from moderate to high (Faille et al., 2010). This hydrophobic character it thought to be linked to the presence of an exosporium on the outer spore membrane composed of proteins, polysaccharides, lipids and ash (Faille et al., 2010; Sagong et al., 2013). Spores are more hydrophobic than vegetative cells. It has been suggested that the increased hydrophobicity of the spores may be due to a relative abundance of protein in the outer coats and exosporium compared with the peptidoglycan on vegetative cell surfaces (Parkar, Flint, Palmer, \& Brooks, 2001). Previous works have shown that a lower $\xi$-potential, i.e. net charge on the spore surface, may be correlated with increased surface attachment (Husmark \& Rönner, 1990), while others did not identify a correlation (Parkar et al., 2001). These different observations reflect the fact that the surface attachment or the location of these bacteria in a complex system is a multifactorial process, combining physical factors such as surface appendages, chemical signaling between cells and chemical interactions.

Furthermore, the component linked to interfaces, namely the emulsifier, could also interact with cells and affect germination and/or growth. Tween 80 is commonly used as an emulsion stabilizer in a wide range of food and personal care products (Henry et al., 2009). Tween-type emulsifiers possess a branched hydrophilic region of three polyoxyethylene chains substituted to a sorbitan ring. The results of the present study revealed an antimicrobial effect of Tween 80 on B. weihenstephanensis KBAB4 spores and on vegetative cells which depended on $\mathrm{pH}$. An effect of Tween 80 on the action of antimicrobial compounds has 
[Texte]

485

486

487

488

489

490

491

492

493

494

495

496

497

498

499

500

501

502

503

504

505

506

507

508

509

510

511

512

513

514

515

516

517

518

previously been mentioned in the context of interactions in food systems (Castro et al., 2009; Jung et al., 1992; Krogsgard-Nielsen et al., 2017). Tween 80 may have hampered the antimicrobial properties of isoeugenol in an emulsion (Krogsgard-Nielsen et al., 2017). The solubilization capacity of the emulsifier on isoeugenol was so strong that it prevented the antimicrobial compound from penetrating the cell membrane. Alternatively, Tween 80 might affect the biofilm or individual cells in a way that makes them less susceptible to isoeugenol, by interacting with membrane proteins which made them more hydrophilic and therefore less prone to interaction with the essential oil (Krogsgard-Nielsen et al., 2017). This remark might also have implications for the use of other hydrophobic substances: Krsta et al. (2014) showed that Tween 80 reduced the effects of the antibiotic triclosan on Streptococcus agalactiae and S. aureus. In a model salad dressing, the Tween effect was entirely dependent on oil content when nisin was present: (i) at $23 \%$ oil, Tween had an antagonistic effect with nisin; (ii) at 11 $\%$ oil, the presence of Tween increased the preservative effect; (iii) at $46 \%$, Tween had no effect (Castro et al., 2009). In the same way, Jung et al. (1992) demonstrated interactions between nisin, milk and Tween: the addition of Tween 80 has been shown to significantly increase the activity of nisin on L. monocytogenes in milk regardless of fat content. The authors suggested that nisin may adsorb to milk fat globules, which may render it unavailable to destroy microbial cells. Tween, which has the ability to displace proteins from the milk fat globule, may increase nisin availability. These results highlighted the importance of considering ingredient interactions when evaluating the microbial stability of food systems.

Nevertheless, only a few studies have mentioned the testing of the antimicrobial effect of an emulsifier as a function of $\mathrm{pH}$ and its concentrations. In our case, Tween 80 seemed to stress spores and vegetative cells, slowing down germination and growth. In previous works, Tween 80 appears to have affected cell permeability in certain microorganisms to promote both uptake and exit of compounds from the cell though modifications of plasma membrane permeability (Brown \& Winsley, 1969; Noh, Kim, \& Gilliland, 1997; Sattler \& Youmans, 1948). Noh et al. (1997) showed that the influence of Tween 80 was related to alterations in the cellular membrane of the organism on Lactobacillus acidophilus. On Pseudomonas aeruginosa, $0.125 \%$ polysorbate led to the greatest uptake of a dye showing cell membrane permeability (Brown \& Winsley, 1969). Non-ionics had little denaturing action on proteins, the uptake of polysorbate was presumably via hydrogen bonding. Flow cytometry on vegetative cells in the presence of Tween 80 in the medium did not determine whether Tween 80 permeabilized the membrane of $B$. weihenstephanensis KBAB4 cells. Thus, the reduction in growth rate could be due to a modification of the cellular membrane and its properties 
[Texte]

519 (permeability, hydrophobicity/hydrophilicity). Moreover, the synergistic effect between

520

521

522

523

524

525

526

527

528

529

530

531

532

533

534

535

536

537

538

539

540

541

542

543

544

545

546

547

548

549

550

551

Tween 80/pH and Tween 80/organic acid shows that Tween 80 could destabilize the membrane, facilitating the action of $\mathrm{pH}$ or organic acid. Concerning this effect on germination, spore surfaces were hydrophobic, so interactions could have been possible on the surface of the spores with Tween 80 , inhibiting germination mechanisms. Tween 80 is a non-ionic emulsifier and would therefore not be expected to have any charge, although previous studies have shown that droplets stabilized by non-ionic emulsifiers may be charged due to the presence of ionizable surface active impurities (such as free fatty acids) or due to preferential adsorption of hydroxyl ions at high $\mathrm{pH}$ or hydrogen ions at low $\mathrm{pH}$ to the droplet surfaces (Yang, Leser, Sher, \& McClements, 2013).

These interactions between the surface of the spores and Tween 80 could explain in some cases the fact that germination and outgrowth were lower in $\phi=0.35$ emulsions than in $\phi=$ 0.50 emulsions. The interfacial region plays a crucial role in controlling the distribution of molecules in the emulsified system (Pastoriza-Gallego, Losada-Barreiro, \& Bravo-Diaz, 2012). Amphiphilic molecules are primarily located in the interfacial region; meanwhile nonpolar molecules tend to be mainly distributed between the oil and interfacial regions and polar molecules are distributed between the aqueous and interfacial regions (Pastoriza-Gallego et al., 2012). It seems that the effect of the dispersed phase volume fraction on antimicrobial activity observed in our system was due to the distribution of the emulsifier between the aqueous phase and the interface. According to Henry et al. (2009), Tween 80 had a head group size of $0.78 \mathrm{~nm}^{2}$ (average of 3 values in the literature). With the dispersed phase volume fraction, the dispersed phase droplet volume and the concentration of emulsifier in the emulsion, it was possible to calculate the proportion of each emulsifier required to give the surface coverage of dispersed phase droplets for the emulsions produced. In $\phi=0.50$ emulsions, with the concentration of Tween 80 used $(1.5 \%(w / w)$ in final emulsions), all molecules were at the interfaces: there were no free Tween 80 molecules. They were not in contact with the cells, hence the antimicrobial activity due to Tween 80 was limited. On the contrary, in $\phi=0.35$ emulsions, Tween 80 molecules were in excess to cover all droplets, so a share of the molecules remained free. They were therefore in contact with the cells in the aqueous phase and the antimicrobial activity of Tween 80 was higher.

\section{Conclusions}


[Texte]

552 The present study shows that the inhibition of spore germination and growth in the model 553 emulsion depended on several factors: $\mathrm{pH}$ value and the dispersed phase volume fraction.

554 Antimicrobial activity resulted in a reduction in the number of cells capable of germination 555 and outgrowth, a reduction in maximal specific growth rate and an increase in lag times. The 556 effect of the dispersed phase volume fraction was due to a combination of:

557 (i) the lipophilicity of the biocide, hexanoic acid, that may have had an impact on the 558 distribution of organic acid between hexadecane and the aqueous phases;

559 (ii) the antimicrobial activity of the emulsifier Tween 80 detected at the acidic $\mathrm{pH}$ value.

560 The effect of Tween 80 has rarely been described in the literature and this study highlights the 561 caution with which this emulsifier must be used. Furthermore, the addition of Tween 80 in a 562 formulation may improve the antimicrobial activity of preservatives and this model emulsion 563 could be used as a surface treatment for example. The interface phenomena seemed to have a 564 great influence. Future work will focus on the exploration of these phenomena at the interface 565 by the use of biocides with other physical-chemical characteristics (lipophilicity,

566

567

568

569

570

571

572

573

574

575

576

\section{Acknowledgments}

The authors gratefully acknowledge the "Conseil Départemental du Finistère" for their financial support, Pr. Y. Grohens and Dr. B. Saulnier from the "Institut de Recherche Dupuy de Lôme" (IRDL) for their support concerning the $\xi$-potential measurements, the PIMM-DRX platform of the University of Western Brittany (“Université de Bretagne Occidentale, UBO”) for the technical support for microscopic observations and the PRISM platform for access to high-field NMR facilities. 
[Texte]

577 References

578 Antolinos, V., Muñoz-Cuevas, M., Ros-Chumillas, M., Periago, P. M., Fernández, P. S., \& Le Marc, Y. (2012). Modelling the effects of temperature and osmotic shifts on the growth kinetics of Bacillus weihenstephanensis in broth and food products. International Journal of Food Microbiology, 158(1), 36ロ41.

Baranyi, J., \& Pin, C. (1999). Estimating bacterial growth parameters by means of detection times. Applied and environmental microbiology, 65(2), 732-736.

Baril, E., Coroller, L., Postollec, F., Leguerinel, I., Boulais, C., Carlin, F., \& Mafart, P. (2011). The wet-heat resistance of Bacillus weihenstephanensis KBAB4 spores produced in a two-step sporulation process depends on sporulation temperature but not on previous cell history. International Journal of Food Microbiology, 146(1), 5762.

Bellon-Fontaine, M.-N., Rault, J., \& van Oss, C. J. (1996). Microbial adhesion to solvents: a novel method to determine the electron-donor/electron-acceptor or Lewis acid-base properties of microbial cells. Colloids and Surfaces B: Biointerfaces, 7(12), 47-53.

Brocklehurst, T. F., \& Wilson, P. D. (2000). The role of lipids in controlling microbial growth. Grasas y aceites-International Journal of Fats and Oils, 51(12), 66-73.

Brown, M. R. W., \& Winsley, B. E. (1969). Effect of polysorbate 80 on cell leakage and viability of Pseudomonas aeruginosa exposed to rapid changes of $\mathrm{pH}$, temperature and tonicity. Microbiology, 56(1), 99-107.

Bundeleva, I. A., Shirokova, L. S., Bénézeth, P., Pokrovsky, O. S., Kompantseva, E. I., \& Balor, S. (2011). Zeta potential of anoxygenic phototrophic bacteria and Ca adsorption at the cell surface: Possible implications for cell protection from $\mathrm{CaCO} 3$ precipitation in alkaline solutions. Journal of Colloid and Interface Science, 360(1), $100 \square 109$.

Buranasuksombat, U., Kwon, Y. J., Turner, M., \& Bhandari, B. (2011). Influence of emulsion droplet size on antimicrobial properties. Food Science and Biotechnology, 20(3), 793800. 
[Texte]

603

604

605

606

607

608

609

610

611

612

613

614

615

616

617

618

619

620

621

622

623

624

625

626

627

Carrera, M., Zandomeni, R. O., Fitzgibbon, J., \& Sagripanti, J.-L. (2007). Difference between the spore sizes of Bacillus anthracis and other Bacillus species. Journal of Applied Microbiology, 102(2), 303312. https://doi.org/10.1111/j.1365-2672.2006.03111.x

Castro, M. P., Rojas, A. M., Campos, C. A., \& Gerschenson, L. N. (2009). Effect of preservatives, tween 20, oil content and emulsion structure on the survival of Lactobacillus fructivorans in model salad dressings. LWT-Food Science and Technology, 42(8), 1428-1434.

Celiktas, O. Y., Kocabas, E. H., Bedir, E., Sukan, F. V., Ozek, T., \& Baser, K. H. C. (2007). Antimicrobial activities of methanol extracts and essential oils of Rosmarinus officinalis, depending on location and seasonal variations. Food Chemistry, 100(2), 553-559.

Desriac, N., Postollec, F., Durand, D., Leguerinel, I., Sohier, D., \& Coroller, L. (2013). Sensitivity of Bacillus weihenstephanensis to acidic changes of the medium is not dependant on physiological state. Food Microbiology, 36(2), $440 \square 446$.

Dong, P., Georget, E., Aganovic, K., Heinz, V., \& Mathys, A. (2016). Inactivation of Bacillus amyloliquefaciens spores by continuous high-pressure-assisted thermal sterilization in an oil-in-water (o/w) emulsion with 10\% soybean oil. European Food Research and Technology, 242(6), 935-942.

Faille, C., Lequette, Y., Ronse, A., Slomianny, C., Garénaux, E., \& Guerardel, Y. (2010). Morphology and physico-chemical properties of Bacillus spores surrounded or not with an exosporium: consequences on their ability to adhere to stainless steel. International journal of food microbiology, 143(3), 125-135.

Griffiths, K. K., Zhang, J., Cowan, A. E., Yu, J., \& Setlow, P. (2011). Germination proteins in the inner membrane of dormant Bacillus subtilis spores colocalize in a discrete cluster. Molecular microbiology, 81(4), 1061-1077. 
[Texte]

628 Guillier, L., Pardon, P., \& Augustin, J.-C. (2005). Influence of stress on individual lag time

629

630

631

632

633

634

635

636

637

638

639

640

641

642

643

644

645

646

647

648

649

650

651

652 distributions of Listeria monocytogenes. Applied and environmental microbiology, 71(6), 2940-2948.

Hansch, C., \& Leo, A. (1995). Exploring Qsar (Vol. 631). American Chemical Society Washington, DC.

Henry, J. V., Fryer, P. J., Frith, W. J., \& Norton, I. T. (2009). Emulsification mechanism and storage instabilities of hydrocarbon-in-water sub-micron emulsions stabilised with Tweens (20 and 80), Brij 96v and sucrose monoesters. Journal of colloid and interface science, 338(1), 201-206.

Hilbig, J., Ma, Q., Davidson, P. M., Weiss, J., \& Zhong, Q. (2016). Physical and antimicrobial properties of cinnamon bark oil co-nanoemulsified by lauric arginate and Tween 80. International Journal of Food Microbiology, 233, 52-59.

Husmark, U., \& Rönner, U. (1990). Forces involved in adhesion of Bacillus cereus spores to solid surfaces under different environmental conditions. Journal of Applied Microbiology, 69(4), 557-562.

Jung, D.-S., Bodyfelt, F. W., \& Daeschel, M. A. (1992). Influence of Fat and Emulsifiers on the Efficacy of Nisin in Inhibiting Listeria monocytogenes in Fluid Milk1. Journal of Dairy Science, 75(2), 387-393.

Krogsgard-Nielsen, C., Kjems, J., Mygind, T., Snabe, T., Schwarz, K., Serfert, Y., \& Meyer, R. L. (2017). Antimicrobial effect of emulsion-encapsulated isoeugenol against biofilms of food pathogens and spoilage bacteria. International journal of food microbiology, $242,7-12$.

Krsta, D., Ku, C., Crosby, I. T., Capuano, B., \& Manallack, D. T. (2014). Bacterial fatty acid synthesis: effect of tween 80 on antibiotic potency against Streptococcus agalactiae and methicillin-resistant Staphylococcus aureus. Anti-Infective Agents, 12(1), 80-84. 
[Texte]

653

654

655

656

657

658

659

660

661

662

663

664

665

666

667

668

669

670

671

672

673

674

675

676

Landry, K. S., Komaiko, J., Wong, D. E., Xu, T., McClements, D. J., \& McLandsborough, L. (2016). Inactivation of Salmonella on Sprouting Seeds Using a Spontaneous Carvacrol Nanoemulsion Acidified with Organic Acids. Journal of Food Protection, 79(7), 11151126.

Leal-Calderon, F., Schmitt, V., \& Bibette, J. (2007). Emulsion science: basic principles. ( $^{\text {nd }}$ ed.). Springer-Verlag New-York.

Ly, M. H., Aguedo, M., Goudot, S., Le, M. L., Cayot, P., Teixeira, J. A., Le, T. M., Belin, J.M., \& Waché, Y. (2008). Interactions between bacterial surfaces and milk proteins, impact on food emulsions stability. Food Hydrocolloids, 22(5), 742-751.

Ly, M. H., Naïtali-Bouchez, M., Meylheuc, T., Bellon-Fontaine, M.-N., Le, T. M., Belin, J.M., \& Waché, Y. (2006). Importance of bacterial surface properties to control the stability of emulsions. International journal of food microbiology, 112(1), 26-34.

Mao, L., Wang, D., Liu, F., \& Gao, Y. (2016). Emulsion Design for the Delivery of $\beta$ Carotene in Complex Food Systems. Critical Reviews in Food Science and Nutrition, $19,1-15$.

McClements, D. J., \& Weiss, J. (2005). Bailey’s Industrial Oil and Fat Products: Processing Technologies Edible Oil and Fat Products-Lipid emulsions (6 ${ }^{\text {th }}$ ed.). Wiley-Blackwell. (Chapter 4).

Membré, J.-M., Leporq, B., Vialette, M., Mettler, E., Perrier, L., Thuault, D., \& Zwietering, M. (2005). Temperature effect on bacterial growth rate: quantitative microbiology approach including cardinal values and variability estimates to perform growth simulations on/in food. International Journal of Food Microbiology, 100, 179-186.

MubarakAli, D., LewisOscar, F., Gopinath, V., Alharbi, N. S., Alharbi, S. A., \& Thajuddin, N. (2018). An inhibitory action of chitosan nanoparticles against pathogenic bacteria 
[Texte]

and fungi and their potential applications as biocompatible antioxidants. Microbial Pathogenesis, 114, 323 $\square 327$.

Murray, D. S. (2016). Influence of Inoculum Preparation upon Sensitivity of Common Food Borne Pathogens to Emulsion Based Antimicrobials. University of MassachusettsAmherst, $\quad$ Masters $\quad$ Theses 330. http://scholarworks.umass.edu/masters_theses_2/330/

Mvou Lekogo, B., Coroller, L., Mathot, A. G., Mafart, P., \& Leguérinel, I. (2010). Modelling the influence of palmitic, palmitoleic, stearic and oleic acids on apparent heat resistance of spores of Bacillus cereus NTCC 11145 and Clostridium sporogenes Pasteur 79.3. International journal of food microbiology, 141(3), 242-247.

Naïtali, M., Dubois-Brissonnet, F., Cuvelier, G., \& Bellon-Fontaine, M.-N. (2009). Effects of $\mathrm{pH}$ and oil-in-water emulsions on growth and physicochemical cell surface properties of Listeria monocytogenes: Impact on tolerance to the bactericidal activity of disinfectants. International journal of food microbiology, 130(2), 101-107.

Neves, M. A., Ung, P., Uemura, K., Takahashi, C., Kobayashi, I., Romano, P., \& Nakajima, M. (2016). Antimicrobial Oil-in-Water Nanoemulsions: Synergistic Effect of Nisin and Carvacrol against Bacillus subtilis. Journal of Food Science and Engineering, 6, 6374.

Noh, D. O., Kim, S. H., \& Gilliland, S. E. (1997). Incorporation of Cholesterol into the Cellular Membrane of Lactobacillus acidophilus ATCC 431211. Journal of Dairy Science, 80(12), 3107-3113.

Parkar, S. G., Flint, S. H., Palmer, J. S., \& Brooks, J. D. (2001). Factors influencing attachment of thermophilic bacilli to stainless steel. Journal of Applied Microbiology, 90(6), 901-908. 
[Texte]

700

701

702

703

704

705

706

707

708

709

710

711

712

713

714

715

716

717

718

719

720

721

722

723

Pastoriza-Gallego, M. J., Losada-Barreiro, S., \& Bravo-Díaz, C. (2012). Effects of acidity and emulsifier concentration on the distribution of Vitamin $\mathrm{C}$ in a model food emulsion. Journal of Physical Organic Chemistry, 25(11), 908-915.

Prachaiyo, P., \& McLandsborough, L. A. (2003). Oil-in-Water Emulsion as a Model System to Study the Growth of Escherichia coli O157: H7 in a Heterogeneous Food System. Journal of food science, 68(3), 1018-1024.

Ribes, S., Fuentes, A., Talens, P., \& Barat, J. M. (2017). Application of cinnamon bark emulsions to protect strawberry jam from fungi. LWT-Food Science and Technology, $78,265-272$.

Robins, M. M., \& Wilson, P. D. (1994). Food structure and microbial growth. Trends in Food Science \& Technology, 5(9), 289-293.

Sagong, H.-G., Cheon, H.-L., Kim, S.-O., Lee, S.-Y., Park, K.-H., Chung, M.-S., Choi, Y.-J., \& Kang, D.-H. (2013). Combined effects of ultrasound and surfactants to reduce Bacillus cereus spores on lettuce and carrots. International journal of food microbiology, 160(3), 367-372.

Sattler, T. H., \& Youmans, G. P. (1948). The effect of “Tween 80,” bovine albumin, glycerol, and glucose on the growth of Mycobacterium tuberculosis var. hominis (H37Rv). Journal of bacteriology, 56(2), 235.

Seale, R. B., Flint, S. H., McQuillan, A. J., \& Bremer, P. J. (2008). Recovery of spores from thermophilic dairy bacilli and effects of their surface characteristics on attachment to different surfaces. Applied and environmental microbiology, 74(3), 731-737.

Terjung, N., Loeffler, M., Gibis, M., Salminen, H., Hinrichs, J., \& Weiss, J. (2014). Impact of lauric arginate application form on its antimicrobial activity in meat emulsions. Food biophysics, 9(1), 88-98. 
[Texte]

Trunet, C., Mtimet, N., Mathot, A.-G., Postollec, F., Leguerinel, I., Sohier, D., Couvert, O., Carlin, F., \& Coroller, L. (2015). Modeling the recovery of heat-treated Bacillus licheniformis Ad978 and Bacillus weihenstephanensis KBAB4 spores at suboptimal temperature and $\mathrm{pH}$ using growth limits. Applied and environmental microbiology, 81(2), 562-568.

van Melis, C. C. J., Almeida, C. B., Kort, R., Groot, M. N., \& Abee, T. (2012). Germination inhibition of Bacillus cereus spores: impact of the lipophilic character of inhibiting compounds. International journal of food microbiology, 160(2), 124-130.

van Melis, C. C. J., Groot, M. N., Tempelaars, M. H., Moezelaar, R., \& Abee, T. (2011). Characterization of germination and outgrowth of sorbic acid-stressed Bacillus cereus ATCC 14579 spores: phenotype and transcriptome analysis. Food microbiology, 28(2), $275-283$.

Wilson, P. D. G., Brocklehurst, T. F., Arino, S., Thuault, D., Jakobsen, M., Lange, M., Farkas, J., Wimpenny, J.W.T., \& Van Impe, J. F. (2002). Modelling microbial growth in structured foods: towards a unified approach. International journal of food microbiology, 73(2), 275-289.

Yang, Y., Leser, M. E., Sher, A. A., \& McClements, D. J. (2013). Formation and stability of emulsions using a natural small molecule surfactant: Quillaja saponin (Q-Naturale $\left.{ }^{\circledR}\right)$. Food Hydrocolloids, 30(2), 589-596.

Zalazar, A. L., Gliemmo, M. F., \& Campos, C. A. (2016). Effect of stabilizers, oil level and structure on the growth of Zygosaccharomyces bailii and on physical stability of model systems simulating acid sauces. Food Research International, 85, 200-208.

\section{Web reference}

EUR-Lex, Access to European Union Law, last accessed date: 11-02-2017 
[Texte]

749 http://eur-lex.europa.eu/homepage.html?locale=en 
Fig. 1. Confocal microscopy observations of inoculated $\phi=0.50$ emulsions with labeling of Bacillus spores with Thioflavin T (green) and the dispersed phase with Nile Red (red). (a, b, c: 2D observations; d: 3D observations). (For interpretation of the references to colour in this figure legend, the reader is referred to the web version of this article.)

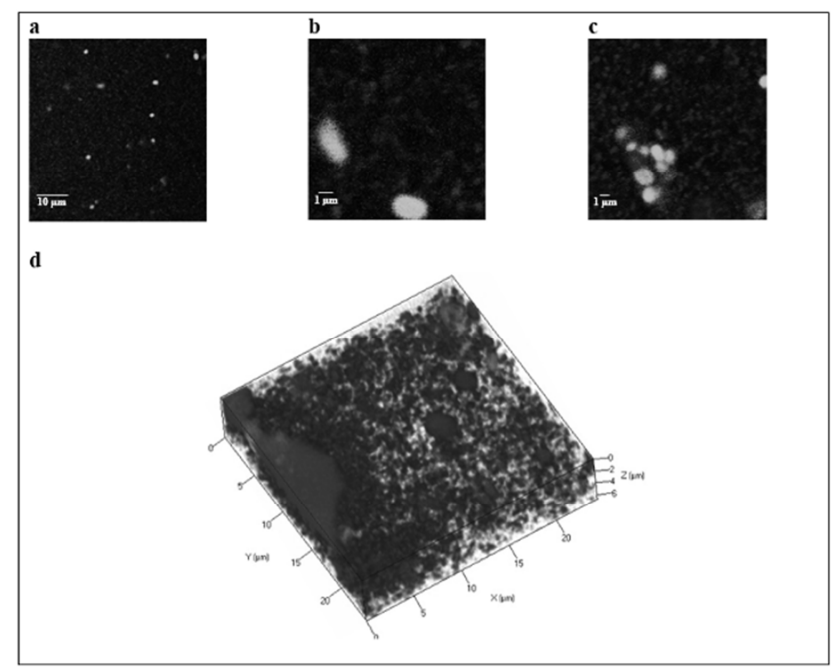

Fig. 2. D/DO for weak acids in distilled water or in emulsions as a function of $\mathrm{pH}$ at different hexadecane ratio $(\phi)$ (assuming a unique diffusion mechanism) (D/DO: ratio of self-diffusion coefficient in emulsion to self-diffusion coefficient of bulk component; $\phi$, dispersed phase volume ratio).

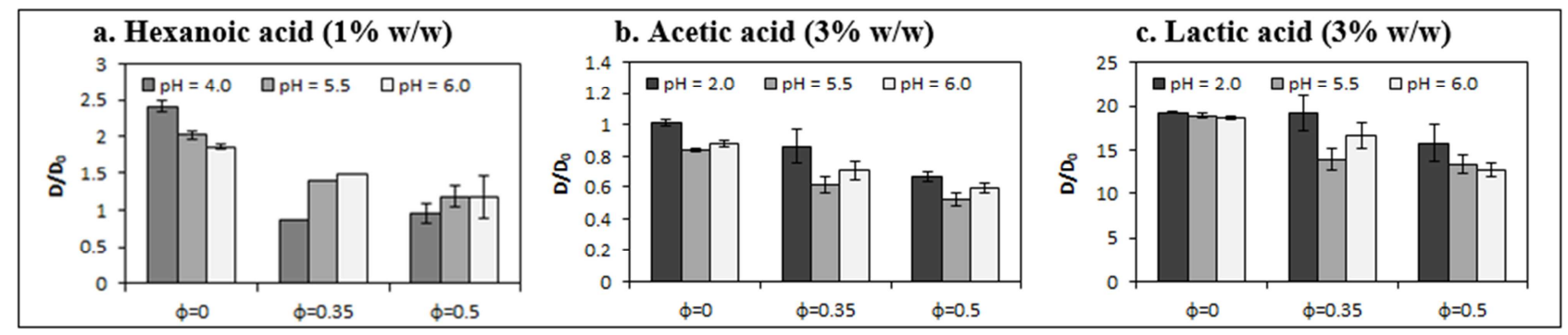

Fig. 3. Maximal growth rate ( $\mu \mathrm{max})$ at $\mathrm{pH} 6.0$ and 5.5 in nutrient broth in the presence of Tween at different concentrations from $0 \%$ to $10 \%{ }^{*}, * *$ : $\mu$ max significantly different from $\mu$ max obtained without Tween 80 following a Student t-test $(\mathrm{P}<0.05))$.

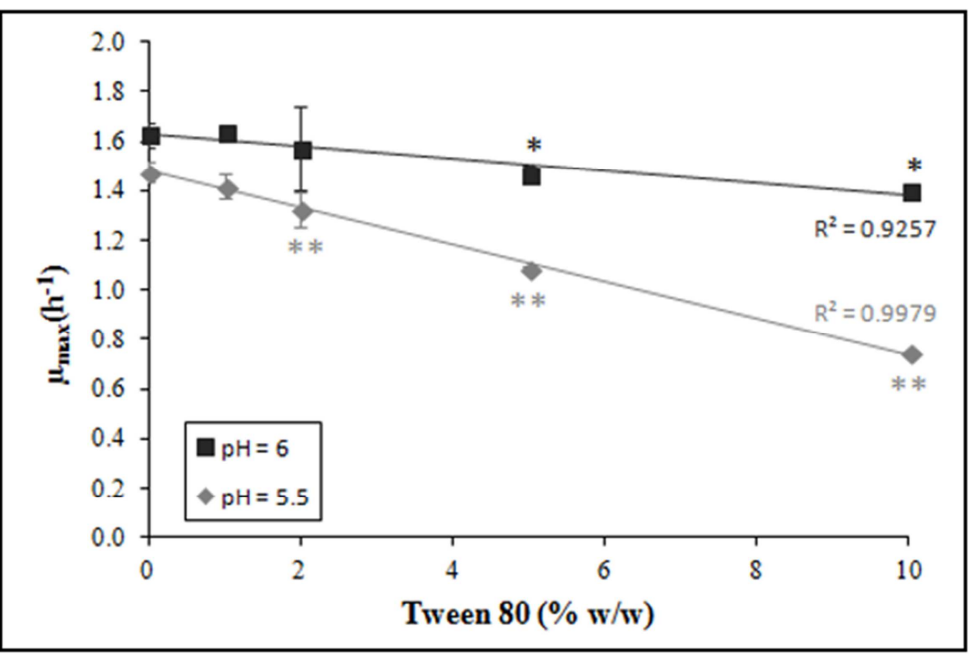


Fig. 4. Frequency distribution of individual lag times during growth of $B$. weihenstephanensis KBAB4 in nutrient broth without Tween 80 (black histogram) and with $5 \%(w / w)$ of Tween 80 (gray shaped histogram): a- at a pH 6.0; b- at a pH 5.5 .
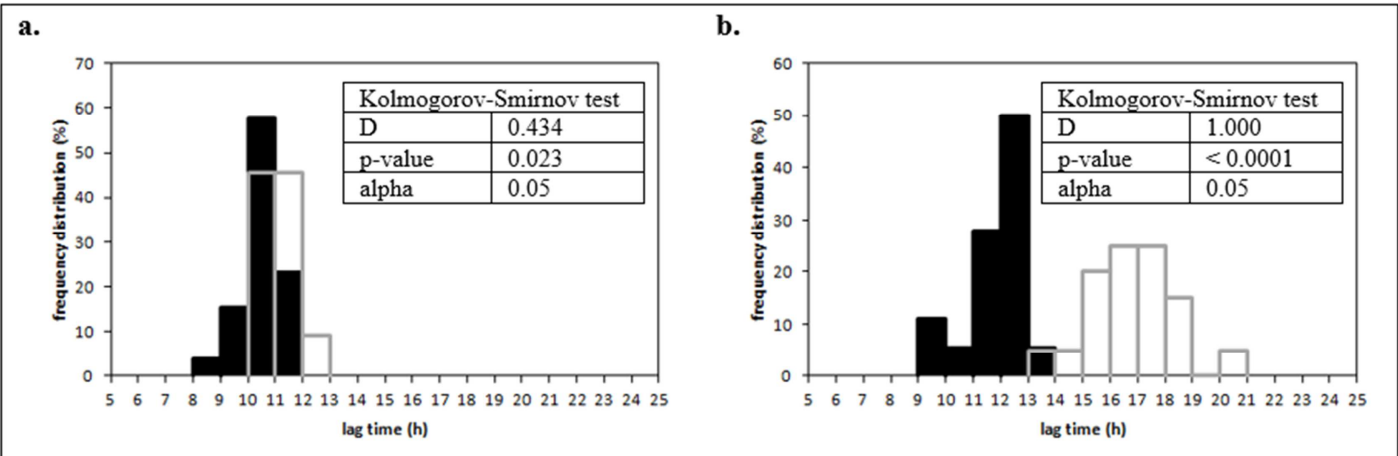

Fig. 5. Flow cytometry-derived scatterplots of green fluorescence (FL1) versus forward-scatter intensities (FSC) of Syto ${ }^{\circledR}$-stained B. weihenstephanensis KBAB4 spores during germination and growth. Events in different quadrants correspond to dormant refractive spores (I), germinated spores (II), and outgrowing spores (III).

a. at $\mathrm{pH} 5.5$ in nutrient broth without Tween 80

b. at $\mathrm{pH} 5.5$ in nutrient broth with $5 \%(\mathrm{w} / \mathrm{w})$ Tween 80

c. at pH 5.5 in nutrient broth with $10 \%(w / w)$ Tween 80 .

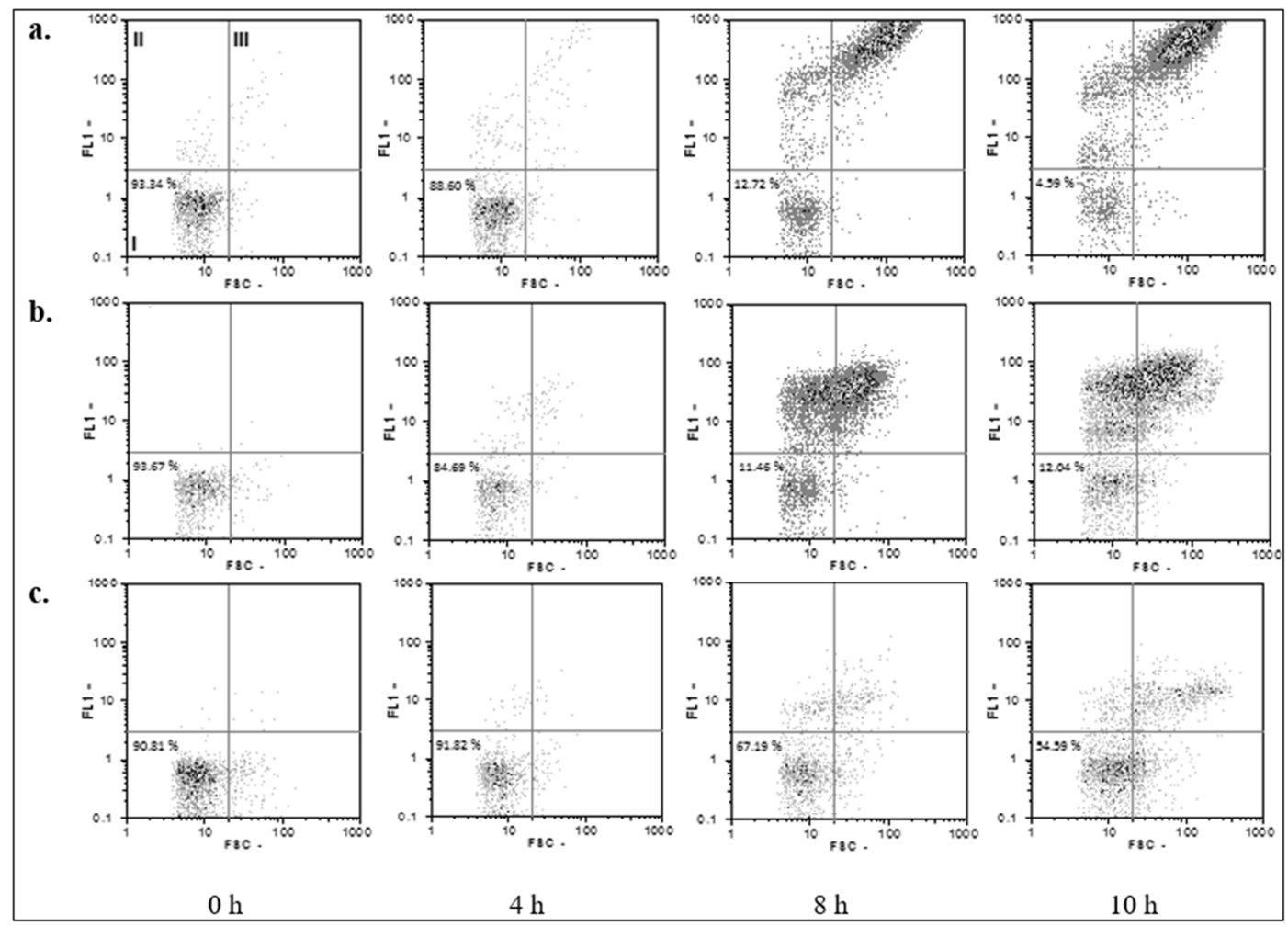

